\title{
DETERMINAN PENGAMBILAN KEPUTUSAN LINDUNG NILAI (HEDGING) DENGAN INSTRUMEN DERIVATIF VALUTA ASING PADA PERUSAHAAN MANUFAKTUR
}

\author{
Verawaty $^{1}$, Ade Kemala Jaya ${ }^{2}$, Megawati ${ }^{3}$ \\ Fakultas Ekonomi dan Bisnis, Universitas Bina Darma \\ verawaty_mahyudin@yahoo.com ${ }^{1}$,jaya_ade@yahoo.com ${ }^{2}$, pianzamegawatigmail.com ${ }^{3}$
}

\begin{tabular}{l} 
ARTICLE INFO \\
\hline Article history: \\
Received 7 Januari 2019 \\
Received in Revised 17 April 2019 \\
Accepted 2 April 2019 \\
\hline Keywords: \\
Corporate Value, Liquidity, \\
Leverage, Growth \\
Opportunity, Financial \\
Distress, Firm Size, \\
Hedging Decision
\end{tabular}

ARTICLE INFO

\begin{abstract}
Hedging is an alternative of risk management that aims to protect the assets of company from losses caused by the risk. This research was aimed to analyze the influence of corporate value, liquidity, leverage, growth opportunity, financial distress and firm size to the hedging decision on manufacturing companies listed in Indonesia Stock Exchange. The samples were 24 manufacturing companies which were listed in Indonesia Stock Exchange in the period of 2016-2017 which had been selected by using the purposive sampling technique. The data analysis technique used logistic regression. The research result showed that corporate value, liquidity and growth opportunity did not give any significant influence to the hedging decision whereas leverage, financial distress and firm size had significant influence to the hedging decision.
\end{abstract}

Hedging adalah alternatif manajemen risiko yang bertujuan untuk melindungi aset perusahaan dari kerugian yang diakibatkan oleh risiko. Penelitian ini bertujuan untuk menganalisis pengaruh corporate value, liquidity, leverage, growth opportunity, financial distress dan firm size terhadap keputusan hedging pada perusahaan manufaktur yang terdaftar di Bursa Efek Indonesia. Sampel yang digunakan adalah 24 perusahaan manufaktur yang terdaftar di Bursa Efek Indonesia periode 2016-2017 dengan menggunakan teknik purposive sampling. Teknik analisis data yang digunakan adalah analisis regresi logistik. Hasil penelitian ini menunjukkan bahwa variabel corporate value, liquidity, dan growth opportunity tidak berpengaruh signifikan terhadap keputusan hedging, sedangkan variabel leverage, financial distress dan firm size berpengaruh signifikan terhadap keputusan hedging.

AKUISISI : Jurnal Akuntansi

Website : http://www.fe.ummetro.ac.id/ejournal/index.php/JA

This is an open access article distributed under the terms of the Creative Commons Attribution 4.0 International License, which permits unrestricted use, distribution, and reproduction in any medium, provided the original work is properly cited. 


\section{PENDAHULUAN}

Semakin berkembangnya zaman membuat perusahaan menjadi lebih mudah untuk mengakses pasar internasional, baik untuk mencari dan melakukan impor bahan baku yang lebih murah dari negara lain maupun memperluas cakupan penjualan produknya ke berbagai negara melalui ekspor. Perdagangan internasional dapat berdampak meningkatkan persaingan dan fluktuasi harga pasar yang mengakibatkan meningkatnya resiko usaha yang harus ditanggung perusahaan. Resiko yang akan dihadapi oleh perusahaan dalam transaksinya dapat disebabkan oleh faktor eksternal seperti fluktuasi tingkat suku bunga, kurs valuta asing ataupun harga komoditas yang berdampak negatif terhadap arus kas, nilai perusahaan, serta dapat mengancam kelangsungan hidup perusahaan (Putro dan Chabachib, 2012). Resiko usaha akan berdampak pada kondisi perusahaan baik secara langsung maupun tidak langsung (Sherlita, 2007).

Kondisi fluktuasi nilai tukar rupiah terhadap mata uang lain khususnya dari sisi hard currencies dapat dilihat di Indonesia dalam beberapa tahun terakhir. Nilai tukar rupiah per dollar pada 30 Desember 2016 sebesar Rp13.436,00 pada 28 Desember 2017 sebesar Rp 13,560.00 dan pada 23 Maret 2018 sebesar Rp 13,780.00 (kurs referensi Bank Indonesia).

Kondisi fluktuasi nilai tukar ini dapat berpengaruh terhadap nilai arus kas perusahaan. Nilai arus kas yang diterima perusahaan dalam berbagai satuan mata uang dapat terkena dampak kurs masing-masing mata uang tersebut saat dikonversi menjadi mata uang domestik, begitu pula dengan nilai kas keluar perusahaan yang tergantung pada nilai masing-masing mata uang sehingga terjadi kenaikan nilai piutang dan hutang setelah dilakukan konversi. Dari sisi hutang tentu saja depresiasi nilai tukar rupiah akan merugikan perusahaan karena nilai hutang mengalami kenaikan tetapi dari sisi piutang akan menguntungkan perusahaan karena nilai pengembalian piutang meningkat setelah dikonversi ke mata uang rupiah. Pengaruh fluktuasi kurs terhadap nilai kas masa depan ini disebut eksposur transaksi. Eksposur transaksi dapat menyebabkan dampak signifikan terhadap laba perusahaan (Madura, 2006).

Untuk mengantisipasi dampak negatif resiko fluktuasi kurs valuta asing serta melindungi kepentingan para pemegang saham, maka perusahaan multinasional melakukan kebijakan hedging dengan instrumen derivatif. Hedging merupakan kontrak yang bertujuan melindungi perusahaan dari resiko pasar (Subramanyam dan Wild, 2012). Aktivitas hedging dapat dilakukan dengan menggunakan instrumen derivatif yaitu opsi, kontrak forward, kontrak futures, dan swap (Sunaryo, 2009).

Indonesia sebagai negara berkembang, penggunaan kebijakan hedging merupakan salah satu cara yang digunakan perusahaan untuk mengurangi resiko yang dapat di sebabkan oleh fluktuasi kurs valuta asing yang merugikan. Fluktuasi kurs valuta asing adalah salah satu resiko pasar yang dapat diminimalisir oleh manajemen resiko melalui aktivitas hedging dengan menggunakan instrumen derivatif. Resiko ini disebabkan oleh aktivitas bisnis luar negeri yang dilakukan perusahaan dalam melakukan perdagangan internasional untuk kegiatan jual beli produk dan jasa mereka. Jenis resiko ini termasuk dalam eksposur valuta asing, yaitu resiko yang disebabkan oleh seberapa jauh suatu perusahaan dipengaruhi oleh perubahan kurs valuta asing (Kuncoro, 2001).

Strategi hedging yang digunakan oleh perusahaan atas transaksi-transaksi keuangannya, instrumen derivatif merupakan salah satu alternatif dalam pasar modal yang cukup berperan. Derivatif merupakan kontrak antara dua pihak untuk membeli atau menjual sejumlah barang (aset finansial ataupun komoditas) pada tanggal yang telah disepakati di masa yang akan datang dengan harga yang telah disetujui saat ini (Utomo, 2000). Penggunaan kebijakan hedging dengan instrumen derivatif mengalami peningkatan dalam beberapa tahun terakhir di negara-negara maju, namun kajian empiris mengenai determinan kebijakan hedging masih 
terbatas dan membutuhkan penelitian lebih luas terutama di negara-negara berkembang (Khediri, 2010).

Determinan yang akan dibahas dalam penelitian ini adalah corporate value (nilai perusahaan), liquidity (likuiditas), leverage, growth opportunity (kesempatan tumbuh), financial distress, firm size (ukuran perusahaan). Pada penelitian ini, sektor manufaktur dipilih sebagai objek penelitian karena sektor manufaktur merupakan salah satu perusahaan dengan jumlah emiten terbanyak di Bursa Efek Indonesia dan merupakan perusahaan yang di dalamnya terjadi proses pengelolaan bahan baku menjadi barang jadi. Selain itu perusahaan manufaktur juga berhubungan langsung dengan daya beli masyarakat sehari-hari dan perusahaan akan selalu berproduksi serta membutuhkan keputusan yang tepat dalam hal pengalokasian keuangan perusahaan, sehingga pengambilan keputusan hedging pada perusahaan manufaktur lebih terlihat dan menjadi daya tarik serta pertimbangan bagi investor yang ingin berinvestasi di perusahaan manufaktur.

Teori yang digunakan ada adalah teori keagenan atau agency theory dikemukakan oleh Michael C. Jensen dan William H. Meckling pada tahun 1976. Jensen dan Meckling dalam Verawaty, dkk (2016), menggambarkan hubungan agency sebagai suatu kontrak di bawah satu atau lebih (principal) yang melibatkan orang lain (agent) untuk melaksanakan beberapa layanan bagi mereka dengan melibatkan pendelegasian wewenang pengambilan keputusan kepada agen. Teori keagenan merupakan basis teori yang mendasari praktek bisnis perusahaan yang dipakai selama ini. Prinsip utama teori ini menyatakan adanya hubungan kerja antara pihak yang memberi wewenang (prinsipal) dengan yang menerima wewenang (agen). Verawaty, dkk (2016), menyatakan bahwa inti dari hubungan keagenan adalah terdapat pemisahan antara kepemilikan dan pengelolaan perusahaan. Agency theory menjelaskan adanya benturan kepentingan antara principal dana agen.

Pada teori keagenan yang disebut principal adalah pemegang saham dan yang disebut agen adalah manajemen yang mengelola perusahaan. Principal diasumsikan hanya tertarik pada pengambilan keuangan yang diperoleh dari investasi mereka pada perusahaan, sedangkan agen diasumsikan akan menerima kepuasan tidak hanya dari kompensasi keuangan tetapi juga dari tambahan lain yang terlibat dalam hubungan keagenan (Anthony dan Govindarajan, 2005 dalam Verawaty, dkk, 2016).

Tujuan utama perusahaan adalah memaksimalkan kemakmuran pemegang saham. Pihak manajemen diharapkan bertindak dan mengambil keputusan untuk kepentingan pemegang saham. Namun, dalam prakteknya sering terjadi konflik antara pihak manajemen dengan pemegang saham. Konflik tersebut terjadi pada saat proporsi kepemilikan manajer atas saham perusahaan kurang dari $100 \%$ sehingga manajer cenderung mengutamakan kepentingan pribadi dan tidak berdasarkan pada tujuan perusahaan yaitu memaksimalkan nilai perusahaan dalam pengambilan keputusan keuangan khususnya keputusan pendanaan (Bestavino, 2013 dalam Verawaty, dkk, 2016).

Verawaty, dkk (2016) juga menggunakan asumsi sifat dasar manusia untuk menjelaskan teori tentang agensi, yaitu manusia pada umumnya mementingkan diri sendiri (self interest), manusia memiliki daya pikir terbatas mengenai persepsi masa mendatang (bounded rationality), dan manusia selalu menghindari risiko (risk adverse). Salah satu sifat dasar manusia adalah self interest artinya mementingkan diri sendiri dan tidak mau berkorban untuk orang lain. Sesuai dengan asumsi tersebut, maka manajer akan mengambil kebijakan yang menguntungkan dirinya sebelum memberikan manfaat kepada pemegang saham.

Jika dikaitkan dengan penelitian ini, teori agensi berperan dan mendasari praktek bisnis perusahaan yang akan meningkatkan keputusan hedging dengan memaksimalkan kemakmuran pemegang saham. Ketika pengambilan keputusan keuangan, teori agensi berperan pada kepemilikan manajerial yang lebih mengutamakan kepentingan pribadi bukan kepentingan pemegang saham atau kepemilikan institusional. 


\section{METODOLOGI PENELITIAN}

\subsection{Populasi dan Sampel}

Metode pemilihan sampel pada penelitian ini ditentukan dengan metode purposive sampling yang bertujuan agar memperoleh sampel yang respresentatif (mewakili) sesuai dengan kriteria yang ditentukan. Adapun kriteria penentu dalam sampel ini adalah sebagai berikut:

Tabel 2.1

\section{Proses Penyeleksian Sampel Perusahaan}

\begin{tabular}{|c|c|c|}
\hline No. & Kriteria & Jumlah Perusahaan \\
\hline 1. & $\begin{array}{l}\text { Perusahaan manufaktur yang terdaftar di Bursa Efek } \\
\text { Indonesia pada periode } 2016-2017 \text {. }\end{array}$ & 144 \\
\hline 2. & $\begin{array}{l}\text { Perusahaan manufaktur yang tidak termasuk dalam sektor } \\
\text { makanan dan minuman, farmasi, kosmetik dan barang } \\
\text { keperluan rumah tangga, peralatan rumah tangga yang } \\
\text { terdaftar di Bursa Efek Indonesia pada periode } 2016-2017 \text {. }\end{array}$ & $(111)$ \\
\hline 3. & $\begin{array}{l}\text { Perusahaan manufaktur dalam sektor makanan dan } \\
\text { minuman, farmasi, kosmetik dan barang keperluan rumah } \\
\text { tangga, peralatan rumah tangga yang tidak menyediakan } \\
\text { laporan secara berurut-urut pada periode } 2016-2017 \text {. }\end{array}$ & (9) \\
\hline & Jumlah sampel & 24 \\
\hline & Tahun pengamatan & 2 \\
\hline & Jumlah sampel akhir & 48 \\
\hline
\end{tabular}

\subsection{Operasional Variabel}

Penelitian ini dilakukan untuk mengetahui faktor penentu keputusan hedging pada perusahaan manufaktur di Bursa Efek Indonesia dengan menggunakan satu variabel terikat (dependent) dan delapan variabel bebas (independent). Variabel dependent dalam penelitian ini yaitu keputusan hedging dan variabel independent terdiri dari corporate value, liquidity (likuiditas), leverage, growth opportunity (kesempatan tumbuh), financial distress, firm size (ukuran perusahaan), dividend policy (kebijakan dividen), dan institutional ownership (kepemilikan institusi).

Berikut tabel operasional semua variabel penelitian:

Tabel 2.2

\section{Operasional Variabel}

\begin{tabular}{|c|c|c|c|}
\hline Variabel & Definisi Operasional & Indikator & $\begin{array}{l}\text { Skala } \\
\text { Ukur }\end{array}$ \\
\hline $\begin{array}{l}\text { Variabel Dependen: } \\
\text { Keputusan hedging }\end{array}$ & $\begin{array}{l}\text { Strategi yang dilakukan oleh manajer untuk } \\
\text { mengurangi risiko akibat fluktuasi kurs valuta } \\
\text { asing karena melakukan investasi di luar } \\
\text { negeri. Hedging dapat dilakukan dengan } \\
\text { menggunakan instrumen derivatif yaitu } \\
\text { forward, future, opsi, swap. }\end{array}$ & $\begin{array}{l}\text { Melakukan hedging } \\
=1 \text { Tidak melakukan } \\
\text { hedging }=0\end{array}$ & Rasio \\
\hline $\begin{array}{l}\text { Variabel Independen: } \\
\text { 1. Corporate value }\end{array}$ & $\begin{array}{l}\text { Perbandingan atau rasio antara nilai pasar } \\
\text { dengan nilai buku. }\end{array}$ & $\begin{array}{l}\text { Nilai pasar dan nilai } \\
\text { buku }\end{array}$ & Rasio \\
\hline $\begin{array}{l}\text { 2. Likuiditas } \\
\text { (Current Ratio) }\end{array}$ & $\begin{array}{l}\text { Likuiditas dan efisiensi rasio yang mengukur } \\
\text { kemampuan perusahaan untuk melunasi } \\
\text { kewajiban jangka pendeknya dengan aset } \\
\text { lancar. }\end{array}$ & $\begin{array}{l}\text { Aset lancar dan utang } \\
\text { lancer. }\end{array}$ & Rasio \\
\hline 3. Leverage & $\begin{array}{l}\text { Rasio yang membandingkan jumlah hutang } \\
\text { terhadap ekuitas. }\end{array}$ & $\begin{array}{l}\text { Total liabilities dan } \\
\text { total ekuitas }\end{array}$ & Rasio \\
\hline
\end{tabular}


4. Kesempatan Tumbuh (Growth Opportunity)

5. Financial distress

6. Ukuran perusahaan (Size)
Peluang pertumbuhan perusahaan di masa mendatang.

Kondisi dimana perusahaan mengalami kesulitan keuangan sebelum terjadinya kebangkrutan, sehingga membuat perusahaan untuk melakukan likuiditas.

Ukuran perusahaan yang digambarkan melalui jumlah aktivitas dan penjualan perusahaan.
EPS, DPS, harga

Rasio

penutup, ekuitas

Modal kerja, total

Rasio aset, total utang, penjualan, laba ditahan, laba sebelum bunga dan pajak, nilai pasar ekuitas

Total aset

Rasio

\subsection{Teknik Analisis}

Untuk mengetahui pengaruh antara variabel independen terhadap dependen, maka perlu dilakukan suatu analisis. Dalam penelitian ini, analisis yang digunakan adalah analisis regresi logistik. Analisis regresi ini digunakan untuk melihat pengaruh variabel independen terhadap variabel dependen. Pengujian dilakukan untuk melihat perusahaan tersebut "memiliki kebijakan hedging" atau "tidak memiliki kebijakan hedging". Regresi tersebut digunakan karena penelitian Regresi tersebut digunakan karena penelitian ini memiliki variabel dependen yang diukur dengan menggunakan data dummy. Berikut model penelitian:

$$
\begin{aligned}
& \frac{p(x i)}{1-p(x i)}=\beta 0+\beta_{1} X_{1}+\beta_{2} X_{2}+\ldots+\beta_{8} X_{8}+\text { e. } \\
& p(x i) \quad: \text { probabilitas variabel dependen } \\
& \beta 0 \quad \text { : konstanta regresi } \\
& \beta_{1}, \beta_{2} \ldots, X \quad \text { : koefisien regresi } \\
& \mathrm{X}_{1} \quad \text { : corporate value } \\
& \mathrm{X}_{2} \quad \text { : likuiditas } \\
& \mathrm{X}_{3} \quad \text { : leverage } \\
& \mathrm{X}_{4} \quad \text { : growth opportunity } \\
& \mathrm{X}_{5} \quad: \text { financial distress } \\
& \mathrm{X}_{6} \quad: \text { kebijakan dividen } \\
& \mathrm{X}_{7} \quad \text { : kepemilikan institusi } \\
& \mathrm{X}_{8} \quad \text { : ukuran perusahaan } \\
& \text { e : error }
\end{aligned}
$$

\subsection{Pengembangan Hipotesis Penelitian}

\subsubsection{Pengaruh Corporate value terhadap Keputusan Hedging}

Verawaty, dkk (2016) menyatakan bahwa nilai perusahaan dapat memberikan kemakmuran pemegang saham jika harga saham meningkat. Menurut Najibullah (2005) dalam Aslikan dan Rokhmi (2017), market to book value (MBV) menunjukkan nilai sebuah perusahaan yang diperoleh dengan membandingkan nilai pasar perusahaan (market value$M V$ ) dengan nilai bukunya (book value- $B V$ ). Dengan demikian, MTBV yang tinggi menunjukkan perusahaan membutuhkan dana yang lebih besar untuk membiayai pertumbuhannya sehingga perusahaan akan melakukan pinjaman pada pihak lain (pihak asing) yang akan meningkatkan risiko perusahaan, untuk itu maka perusahaan memerlukan hedging.

Berdasarkan penelitian yang dilakukan oleh Istiah (2017), menyatakan bahwa corporate value berpengaruh secara signifikan dan positif terhadap pengambilan keputusan hedging. Namun berbeda dengan Aslikan dan Rokhmi (2017), menunjukkan bahwa 
corporate value tidak berpengaruh signifikan dan negatif terhadap keputusan hedging. Dari beberapa penelitian terdahulu, masih adanya temuan hasil penelitian yang tidak konsisten. Dengan demikian peneliti perlu melakukan pengujian kembali untuk mengetahui konsisten temuan penelitian hedging ke dalam hipotesis sebagai berikut:

\section{H1: Corporate value berpengaruh positif terhadap hedging}

\subsubsection{Pengaruh Liquidity terhadap Keputusan Hedging}

Likuiditas mengacu pada seberapa cepat dan mudah suatu aset dapat diubah menjadi kas. Likuiditas sebenarnya memilik dua dimensi yaitu, kemudahan untuk diubah dan hilangnya nilai. Setiap aset dapat dengan cepat diubah menjadi kas jika diturunkan harganya menjadi cukup rendah. Karenanya, aset yang sangat likuid adalah aset yang dapat dijual dengan cepat tanpa harus kehilangan nilai dalam jumlah yang signifikan. Aset yang tidak likuid adalah aset yang tidak dapat diubah menjadi kas dengan cepat tanpa harus mengalami penurunan nilai yang substansial (Ross dkk, 2009 dalam Damanik dan Muharam, 2015). Menurut Verawaty (2013), likuiditas merupakan kemampuan perusahaan untuk memenuhi kewajiban keuangan pada saat ditagih. Semakin tinggi likuiditas maka semakin rendah penggunaan instrumen derivatif karena resiko kesulitan keuangan yang muncul cenderung rendah dan perusahaan juga memiliki cadangan dana untuk menghadapi resiko.

Penelitian Putro dan Chabachib (2012), Sibarani dkk (2016), Istiah (2017), Guniarti (2014), Aslikan dan Rokhmi (2017), Saragih dan Musdholifah (2017), Widyagoca dan Lestari (2016), Damanik dan Muharam (2015), mengemukakan bahwa likuiditas tidak berpengaruh secara signifikan dalam pengambilan keputusan hedging. Namun, berbeda dengan penelitian yang dilakukan oleh Mediana dan Muharam (2016), menemukan adanya pengaruh positif antara likuiditas dan keputusan hedging. Dari beberapa penelitian terdahulu, masih adanya temuan hasil penelitian yang tidak konsisten. Dengan demikian peneliti perlu melakukan pengujian kembali untuk mengetahui konsisten temuan penelitian hedging ke dalam hipotesis sebagai berikut:

\section{H2: Likuiditas berpengaruh positif terhadap hedging}

\subsubsection{Pengaruh Leverage terhadap Keputusan Hedging}

Rasio leverage atau rasio utang yang biasa dikenal dengan rasio solvabilitas. Rasio leverage adalah rasio yang menunjukkan kemampuan perusahaan untuk memenuhi segala kewajiban finansialnya seandainya perusahaan pada saat itu dilikuidasi. Dengan demikian solvabilitas berarti kemampuan perusahaan untuk membayar utang-utangnya, baik jangka pendek maupun jangka panjang. Sejalan dengan Verawaty (2013), rasio ini dapat melihat seberapa jauh perusahaan dibiayai oleh hutang atau pihak luar dengan kemampuan perusahaan yang digambarkan oleh modal (equity). Adapun menurut Sartono (2014), financial leverage ratio menunjukkan kapasitas perusahaan untuk memenuhi kewajiban baik itu jangka pendek maupun jangka panjang. Leverage menunjukkan proporsi atas penggunaan utang untuk membiayai investasinya. Rasio leverage dalam penelitian ini diproksikan dengan Debt to Equity Ratio. Dengan demikian semakin tinggi leverage maka akan semakin besar tindakan hedging.

Penelitian Putro dan Chabachib (2012), Damanik dan Muharam (2015), Sibarani dkk (2016), Guniarti (2014), Aslikan dan Rokhmi (2017), Andardini (2016), mengemukakan bahwa leverage berpengaruh terhadap pengambilan keputusan hedging. Namun berbeda dengan Istiah (2017), Widyagoca dan Lestari (2016), Mediana dan Muharam (2016) yang menyatakan leverage tidak berpengaruh terhadap pengambilan keputusan hedging. Dari beberapa penelitian terdahulu, masih adanya temuan hasil penelitian yang tidak konsisten. 
Dengan demikian peneliti perlu melakukan pengujian kembali untuk mengetahui konsisten temuan penelitian hedging ke dalam hipotesis sebagai berikut:

\section{H3: Leverage berpengaruh positif terhadap hedging}

\subsubsection{Pengaruh Growth Opportunity terhadap Keputusan Hedging}

Kesempatan pertumbuhan perusahaan yang tinggi menunjukkan nilai pasar yang semakin baik di antara perusahaan lainnya. Hal itu membuat perusahaan percaya diri untuk menggunakan dana eksternal untuk penggunaan pertumbuhan perusahaan, selain itu membuat calon investor bersedia menanamkan dananya kepada perusahaan yang memiliki kesempatan pertumbuhan perusahaan yang tinggi, karena dinilai dapat menjadi sarana investasi yang baik. Nilai dari proksi kesempatan pertumbuhan perusahaan yang semakin besar membuat perusahaan lebih banyak menggunakan hutang sebagai sumber dana (Chen, 2006 dalam Sibarani dkk, 2016). Semakin tinggi growth opportunity, berarti probabilitas perusahaan semakin besar untuk melakukan hedging. Sebaliknya apabila variabel growth opportunity rendah, maka probabilitas perusahaan melakukan hedging akan menurun.

Penelitian Putro dan Chabachib (2012), Saragih dan Musdholifah (2017), Mediana dan Muharam (2016), Aslikan dan Rokhmi (2017) mengemukakan bahwa growth opportunity berpengaruh positif dan signifikan pada pengambilan keputusan hedging. Namun berbeda dengan Damanik dan Muharam (2015), Sibarani dkk (2016), Widyagoca dan Lestari (2016) yang menyatakan growth opportunity tidak berpengaruh signifikan pada pengambilan keputusan hedging. Dari beberapa penelitian terdahulu, masih adanya temuan hasil penelitian yang tidak konsisten. Dengan demikian peneliti perlu melakukan pengujian kembali untuk mengetahui konsisten temuan penelitian hedging ke dalam hipotesis sebagai berikut:

\section{H4: Growth opportunity berpengaruh positif terhadap hedging}

\subsubsection{Pengaruh Financial Distress terhadap Keputusan Hedging}

Financial distress adalah kondisi yang menggambarkan keadaan sebuah perusahaan yang sedang mengalami kesulitan keuangan, artinya perusahaan berada dalam posisi yang tidak aman dari ancaman kebangkrutan atau kegagalan pada usaha perusahaan tersebut. Apabila nilai hasil perhitungan menunjukkan angka yang rendah, maka perusahaan tersebut termasuk dalam perusahaan yang akan lebih berhati-hati dalam mengelola keuangannya, sehingga lebih memungkinkan untuk mencari suatu mekanisme pengalihan resiko yaitu aktivitas hedging. Dengan demikian, sebuah perusahaan yang mempunyai indikasi kebangkrutan dari perhitungan financial distress akan mendorong pihak manajemen untuk melindungi perusahaan tersebut dari berbagai resiko termasuk resiko pasar dengan melakukan aktivitas hedging.

Penelitian Putro dan Chabachib (2012), Guniarti (2014), mengemukakan financial distress tidak berpengaruh signifikan terhadap hedging. Namun berbeda dengan penelitian Aslikan dan Rokhmi (2017), mengemukakan financial distress berpengaruh positif signifikan terhadap hedging. Dari beberapa penelitian terdahulu, masih adanya temuan hasil penelitian yang tidak konsisten. Dengan demikian peneliti perlu melakukan pengujian kembali untuk mengetahui konsisten temuan penelitian hedging ke dalam hipotesis sebagai berikut:

H5: Financial distress berpengaruh negatif terhadap hedging 


\subsubsection{Pengaruh Firm Size terhadap Keputusan Hedging}

Ukuran perusahaan digunakan sebagai salah satu indikator mengenai seberapa besar perusahaan itu telah berkembang. Menurut Verawaty (2013), umumnya perusahaan besar memiliki total aset yang besar pula sehingga dapat menarik investor untuk menanamkan modalnya pada perusahaan tersebut dan akhirnya saham tersebut mampu bertahan pada harga yang tinggi. Kadang kala sering pula dijumpai perbedaan terkait kemampuan untuk mendapatkan dana atau modal. Perusahaan yang besar umumnya memiliki fleksibilitas dan aksesibilitas yang tinggi dalam masalah pendanaan melalui pasar modal, sehingga perusahaan besar memiliki kemudahan dan kemampuan lebih dalam mendapatkan dana. Perusahaan yang lebih besar cenderung memiliki sumber permodalan yang lebih terdiversifikasi, sehingga ukuran perusahaan merupakan proksi kebalikan dari kemungkinan kebangkrutan. Biaya menambah hutang dan modal sendiri juga berhubungan dengan ukuran perusahaan. Perusahaan kecil cenderung membayar biaya modal sendiri dan biaya hutang jangka panjang lebih mahal dari pada perusahaan besar, sehingga perusahaan kecil mungkin menyukai hutang jangka pendek daripada meminjam hutang jangka panjang karena biayanya yang lebih rendah. Salah satu cara yang dapat dilakukan untuk mengelola risiko ini adalah dengan melakukan aktivitas hedging. Semakin besar suatu perusahaan semakin besar risiko yang timbul, maka semakin mungkin perusahaan untuk melakukan hedging. Perusahaan yang lebih besar akan lebih banyak melakukan hedging dibandingkan dengan perusahaan dengan ukuran yang lebih kecil.

Penelitian Putro dan Chabachib (2012), Damanik dan Muharam (2015), Sibarani dkk (2016), Istiah (2017), Saragih dan Musdholifah (2017), mengemukakan bahwa firm size berpengaruh positif dan signifikan pada pengambilan keputusan hedging. Dari beberapa penelitian terdahulu, masih adanya temuan hasil penelitian yang tidak konsisten. Dengan demikian peneliti perlu melakukan pengujian kembali untuk mengetahui konsisten temuan penelitian hedging ke dalam hipotesis sebagai berikut:

\section{H6: Firm size berpengaruh positif terhadap hedging}

\section{HASIL DAN PEMBAHASAN}

\subsection{Menilai Model Fit}

Langkah pertama adalah menilai overall fit model terhadap data. Beberapa tes dilakukan untuk menilai hal ini. Cara pertama adalah melalui fungsi likehood, yaitu membandingkan angka -2 log likehood pada awal (block 0 ) dan angka -2 log likehood pada block 1. Jika terjadi penurunan angka $-2 \log$ likehood maka menunjukkan model regresi yang baik. Hasil model penelitian menunjukkan perbandingan antara nilai -2 log likehood pada blok awal dan angka -2 log likehood pada blok akhir. Hasil perhitungan nilai -2 log likehood terlihat bahwa nilai blok awal (block 0) adalah 63.510 dan nilai -2 log likehood pada blok akhir (block 1) adalah 21.734 mengalami penurunan yang menunjukkan model regresi yang baik.

\subsection{Uji Nilai Hosmer and Lemeshow's Goodness of Fit Test}

Menguji hipotesis nol bahwa data empiris cocok atau sesuai dengan model (tidak ada perbedaan antara model dengan data sehingga model dapat dikatakan fit). Jika nilai statistik Hosmer and Lemeshow Goodness of fit lebih besar dari 0.05, maka hipotesis nol tidak dapat ditolak dan berarti model mampu memprediksi nilai observasinya atau dapat dikatakan model dapat diterima karena cocok dengan data observasinya. Hasil uji menunjukkan bahwa 
besarnya nilai statistik Hosmer and Lemeshow Goodness of Fit sebesar 1,806 dengan probabilitas signifikansi 0,986 yang nilainya di atas 0,05 sehingga $\mathrm{H} 0$ diterima. Hal ini berarti model regresi layak dipakai untuk analisis selanjutnya.

\subsection{Uji Nilai Cox and Snell's R Square}

Nagelkerke's $R$ Square merupakan modifikasi dari koefisien Cox and Snell untuk memastikan bahwa nilainya bervariasi dari 0 (nol) sampai satu (1). Nilai Nagelkerke's $R$ Square dapat diinterpretasikan seperti nilai $\mathrm{R}^{2}$ pada multiple regression. Tujuannya adalah mengetahui seberapa besar kombinasi variabel independen mampu menjelaskan variabel dependen. Model summary menunjukkan nilai Nagelkerke's $R$ Square sebesar 0,792. Hal ini menggambarkan bahwa model mempunyai kekuatan prediksi model sebesar 79,2\% yang dijelaskan oleh enam variabel Corporate value, liquidity, leverage, growth opportunity, financial disstres, firm size, sedangkan 20,8\% dijelaskan oleh variabel lainnya di luar variabel.

\subsection{Analisis Regresi}

Tabel 4.1

Variables in the Equation

\begin{tabular}{|c|c|c|c|c|c|c|c|}
\hline & & B & S.E. & Wald & Df & Sig. & $\operatorname{Exp}(B)$ \\
\hline \multirow[t]{7}{*}{ Step $1^{\mathrm{a}}$} & CP & 7.359 & 274.612 & .001 & 1 & .979 & 1569.726 \\
\hline & LQ & -.526 & .405 & 1.684 & 1 & .194 & .591 \\
\hline & LEV & -5.192 & 2.889 & 3.229 & 1 & .072 & .006 \\
\hline & GO & .712 & .468 & 2.318 & 1 & .128 & 2.038 \\
\hline & FD & -1.811 & 1.056 & 2.940 & 1 & .086 & .164 \\
\hline & FS & 1.959 & .861 & 5.180 & 1 & .023 & 7.094 \\
\hline & Constant & -24.369 & 11.728 & 4.318 & 1 & .038 & .000 \\
\hline
\end{tabular}

a. Variable(s) entered on step 1: CP, LQ, LEV, GO, FD, FS.

Sumber: Data diolah, 2018

Setelah melakukan analisis regresi logistik dari tabel 4.1, maka nilai-nilai koefisien regresi tersebut dapat dimasukkan ke dalam persamaan regresi yang disusun dalam persamaan regresi logistik sebagai berikut:

$$
\begin{aligned}
& {[P(H E D G) / 1-P(H E D G)]=-24.369+7.359 \mathrm{CP}-0.526 \mathrm{LQ}-5.129 \mathrm{LEV}+0.712 \mathrm{GO}-} \\
& 1.811 \mathrm{FD}+1.959 \mathrm{FS}+\mathrm{e}
\end{aligned}
$$

Persamaan tersebut dapat menunjukkan jika seluruh variabel bebas yaitu corporate value, liquidity, leverage, growth opportunity, financial disstres, firm size bernilai 0, maka aksesibilitas hedging nilainya negatif yaitu -24.369 . Variabel corporate value memiliki koefisien yang positif yaitu 7.359. Hal ini menunjukkan bahwa setiap peningkatan corporate value sebesar 1, maka hedging akan meningkat sebesar 7.359 dengan asumsi bahwa variabel independennya tetap.

Variabel liquidity memiliki koefisien yang negatif yaitu -0.526 . Hal ini menunjukkan bahwa setiap peningkatan liquidity sebesar 1, maka hedging akan menurun sebesar -0.526 . Variabel leverage memiliki koefisien yang negatif yaitu -5.129. Hal ini menunjukkan bahwa setiap peningkatan leverage sebesar 1, maka hedging akan menurun sebesar -5.129 dengan asumsi bahwa variabel independennya tetap. Variabel growth opportunity memiliki koefisien yang positif yaitu 0.712 . Hal ini menunjukkan bahwa setiap peningkatan growth opportunity sebesar 1, maka hedging akan meningkat sebesar 0.712 . 
Variabel financial disstres memiliki koefisien yang negatif yaitu -1.811. Hal ini menunjukkan bahwa setiap peningkatan financial disstres sebesar 1, maka hedging akan menurun sebesar -1.811 dengan asumsi bahwa variabel independennya tetap. Variabel firm size memiliki koefisien yang positif yaitu 1.959. Hal ini menunjukkan bahwa setiap peningkatan firm size sebesar 1, maka hedging akan menurun sebesar 1.959 dengan asumsi bahwa variabel independennya tetap.

Variabel independen yang tidak berpengaruh terhadap variabel dependen yaitu corporate value dengan nilai signifikansi sebesar 0.979 , liquidity dengan nilai signifikansi sebesar 0.194, growth opportunity dengan nilai signifikansi sebesar 0.128, yang menunjukkan ketiga variabel tersebut memiliki nilai signifikansi $\alpha>0,1$.

\subsection{Pembahasan}

\subsubsection{Corporate Value Berpengaruh Positif terhadap Hedging}

Hasil pengujian hipotesis pertama menunjukkan bahwa hipotesis pertama ditolak. Hasil pengujian menunjukkan bahwa corporate value mempunyai nilai Wald sebesar 0.001 dengan nilai signifikansi sebesar 0.979 yang dimana nilai tersebut lebih besar dari $0,1(\alpha=10 \%)$ dan nilai belta sebesar 7.359. Maka dari itu, berdasarkan hasil hipotesis tersebut menyatakan bahwa corporate value tidak berpengaruh positif terhadap keputusan hedging.

Corporate value dianggap tidak dapat mempengaruhi hedging, karena sumber dana eksternal untuk membiayai investasi perusahaan sangat mahal. Oleh karena itu, ada kemungkinan bagi perusahaan untuk tidak melakukan proyek ini (biaya investasi yang tinggi) yang akibatnya tidak akan meningkatkan nilai perusahaan. Perusahaan cenderung menghadapi tekanan eksternal yang lebih tinggi dalam pengambilan keputusan hedging dan investor pada pasar modal Indonesia tidak memandang market-to-book sebagai sinyal positif bagi kinerja suatu perusahaan. Hasil penelitian ini didukung oleh penelitian yang dilakukan Munthe (2016) dan Paranita (2011) yang menyatakan bahwa Market to Book Value berpengaruh positif terhadap hedging pada perusahaan manufaktur.

Market to Book Value (MTBV) mengindikasikan pandangan investor terhadap nilai perusahaan. Perusahaan yang dipandang baik, sahamnya akan dijual lebih tinggi dibandingkan nilai bukunya. Market To Book Value (MTBV) yang tinggi menunjukkan perusahaan yang memiliki nilai yang tinggi. Perusahaan yang memiliki nilai tinggi cenderung melakukan investasi di luar negeri. Hal ini dilakukan agar perusahaan memiliki going concern yang dapat meningkatkan nilai perusahaan di pasar modal. Karena investor melihat bahwa perusahaan memilki kehidupan berkelanjutan di masa depan. Sebuah perusahaan yang melakukan transaksi di luar negeri cenderung memiliki risiko yaitu fluktuatifnya kurs valuta asing. Karena apabila mata uang lokal terdepresi maka perusahaan akan mengalami kerugian. Dengan semakin tingginya risiko akibat fluktuatifnya kurs valuta asing maka lindung nilai atau hedging yang digunakan semakin besar.

Suatu perusahaan yang memiliki nilai market to book value tinggi berarti memiliki nilai perusahaan yang tinggi, dan artinya perusahaan akan memiliki dana yang cukup tinggi pula. Karena adanya dana yang cukup tinggi tersebut, perusahaan mampu mengatasi risiko yang terjadi karena perubahan mata uang atau kurs dengan dana yang dimiliki tanpa perlu menerapkan hedging dan perusahaan yang memiliki nilai market to book value rendah berarti memiliki nilai perusahaan atau corporate value yang rendah pula dan kemungkinan perusahaan tersebut mengalami risiko karena perubahan kurs pun rendah, sehingga perusahaan tidak berpikir untuk melakukan penerapan hedging untuk usahanya. Hal ini terbukti berdasarkan data corporate value yang menunjukkan tingkat nilai perusahaan yang 
paling tinggi adalah Merck Tbk pada dua tahun berturut-turut, yaitu pada tahun 2016 dan 2017 sebesar $0.0158 \%$ dan $0.013 \%$. Berdasarkan data tersebut menunjukkan bahwa corporate value yang diperoleh perusahaan Merck Tbk memiliki nilai CV paling tinggi namun Merck Tbk tidak melakukan hedging. Dengan demikian, semakin tinggi nilai perusahaan maka akan semakin rendah penggunaan instrumen derivatif karena perusahaan cenderung menghadapi tekanan eksternal yang lebih tinggi dalam pengambilan keputusan hedging.

\subsubsection{Liquidity Berpengaruh Positif terhadap Hedging}

Hasil pengujian hipotesis kedua menunjukkan bahwa hipotesis kedua ditolak. Hasil pengujian menunjukkan bahwa liquidity mempunyai nilai Wald sebesar 1.684 dengan nilai signifikansi sebesar 0,194 yang dimana nilai tersebut lebih besar dari $0,1(\alpha=10 \%)$ dan nilai belta sebesar -0.526. Maka dari itu, berdasarkan hasil hipotesis tersebut menyatakan bahwa liquidity tidak berpengaruh negatif terhadap keputusan hedging.

Liquidity dianggap tidak dapat mempengaruhi hedging, karena perusahaan yang memiliki tingkat likuiditas lebih tinggi akan berusaha semaksimal mungkin untuk tidak mencari sumber pembiayaan eksternal yang mahal. Likuiditas yang tinggi menyebabkan eksposur yang lebih rendah sehingga menghasilkan perusahaan yang memiliki insentif untuk hedging. Beban perusahaan dalam hal kewajiban khususnya dalam jangka pendek kepada pihak lain menjadi berkurang. Perusahaan akan semakin merasa berat apabila ada kewajiban jangka pendek yang menggunakan mata uang asing. Hasil analisis ini konsisten dengan hasil penelitian Putro dan Chabachib (2012), Sibarani dkk (2016), Istiah (2017), Guniarti (2014), Aslikan dan Rokhmi (2017), Saragih dan Musdholifah (2017), Widyagoca dan Lestari (2016), Damanik dan Muharam (2015), mengemukakan bahwa likuiditas tidak berpengaruh secara signifikan dalam pengambilan keputusan hedging. Namun, berbeda dengan penelitian yang dilakukan oleh Mediana dan Muharam (2016), menemukan adanya pengaruh positif antara likuiditas dan keputusan hedging. Adapun Dewi dan Purnawati (2016) serta Goklas dan Wahyudi (2016) yang menemukan adanya pengaruh negatif antara likuiditas dan keputusan hedging.

Hal ini terbukti berdasarkan data liquidity yang menunjukkan tingkat nilai tinggi adalah Industri Jamu dan Farmasi Sido Muncul Tbk pada dua tahun berturut-turut, yaitu pada tahun 2016 dan 2017 sebesar 8.32\% dan 7.81\%. Berdasarkan data tersebut menunjukkan bahwa liquidity yang diperoleh perusahaan Industri Jamu dan Farmasi Sido Muncul Tbk memiliki nilai likuiditas paling tinggi namun Industri Jamu dan Farmasi Sido Muncul Tbk tidak melakukan hedging. Namun, berbeda dengan perusahaan yang paling rendah adalah Unilever Indonesia Tbk sebesar $0.61 \%$ dan $0.63 \%$ dimana Unilever Indonesia Tbk justru melakukan hedging.

Likuiditas mengacu pada seberapa cepat dan mudah suatu aset dapat diubah menjadi kas. Likuiditas sebenarnya memilik dua dimensi yaitu, kemudahan untuk diubah dan hilangnya nilai. Setiap aset dapat dengan cepat diubah menjadi kas jika diturunkan harganya menjadi cukup rendah. Karenanya, aset yang sangat likuid adalah aset yang dapat dijual dengan cepat tanpa harus kehilangan nilai dalam jumlah yang signifikan. Aset yang tidak likuid adalah aset yang tidak dapat diubah menjadi kas dengan cepat tanpa harus mengalami penurunan nilai yang substansial (Ross dkk, 2009 dalam Damanik dan Muharam, 2015). Menurut Munawir (2007), likuiditas menunjukkan kemampuan suatu perusahaan untuk memenuhi kewajiban keuangan yang harus segera dipenuhi, atau kemampuan perusahaan untuk memenuhi kewajiban keuangan pada saat ditagih. Sejalan dengan pernyataan tersebut, Verawaty (2013) menyatakan bahwa liquidity menunjukkan kapasitas dan kapabilitas perusahaan untuk melunasi short term liability. 
Nilai kewajiban tersebut dapat berfluktuasi apabila terjadi fluktuasi mata uang asing terhadap rupiah, sehingga jumlah yang dibayarkan akan meningkat dan membebani perusahaan. Oleh karena itu, semakin likuid kondisi suatu perusahaan akan semakin rendah persentase penerapan kebijakan hedging karena kewajiban jangka pendeknya dapat terpenuhi, sehingga risiko gagal bayar dan kesulitan keuangan dapat dihindari. Menurut Damanik dan Muharam (2015), Ketersediaan dana yang dimiliki perusahaan akan mendorong perusahaan untuk melakukan hedging guna meningkatkan nilai dari perusahaan tersebut. Hal ini sesuai dengan teori hedging yang menyebutkan bahwa hedging dapat meningkatkan nilai perusahaan. Dengan demikian, semakin tinggi likuiditas maka semakin rendah penggunaan instrumen derivatif karena resiko kesulitan keuangan yang muncul cenderung rendah dan perusahaan juga memiliki cadangan dana untuk menghadapi resiko.

\subsubsection{Leverage Berpengaruh Positif terhadap Hedging}

Hasil pengujian hipotesis ketiga menunjukkan bahwa hipotesis ketiga ditolak. Hasil pengujian menunjukkan bahwa leverage mempunyai nilai Wald sebesar 3.229 dengan nilai signifikansi sebesar 0.072 yang dimana nilai tersebut lebih kecil dari $0,1(\alpha=10 \%)$ dan nilai belta sebesar -5.192 . Maka dari itu, berdasarkan hasil hipotesis tersebut menyatakan bahwa leverage berpengaruh negatif terhadap keputusan hedging.

Hasil negatif ini menunjukkan bahwa penurunan debt to equity ratio akan mengakibatkan kenaikan kontrak hedging, begitu juga sebaliknya peningkatan debt to equity ratio akan menyebabkan penurunan kontrak hedging. Hal ini didukung oleh Istiah (2017), Widyagoca dan Lestari (2016), Mediana dan Muharam (2016) yang menyatakan berpengaruh negatif dan signifikan terhadap penggunaan instrumen derivatif sebagai pengambilan keputusan hedging.

Hasil ini signifikan karena perusahaan yang melakukan transaksi internasional memiliki hutang yang dinominasi oleh kurs valuta asing, dengan kata lain besar hutang yang diperoleh perusahaan berasal dari dalam negeri sehingga perusahaan membutuhkan perlindungan dari eksposur valuta asing, dengan demikian perusahaan yang memiliki tingkat hutang tinggi tentu melakukan hedging. Hal ini terbukti berdasarkan data leverage yang menunjukkan tingkat nilai yang paling tinggi adalah Unilever Indonesia Tbk pada dua tahun berturut-turut, yaitu pada tahun 2016 dan 2017 sebesar $2.56 \%$ dan 2.65\%. Berdasarkan data tersebut menunjukkan bahwa leverage yang diperoleh perusahaan Unilever Indonesia Tbk memiliki nilai leverage paling tinggi dan melakukan hedging.

Debt to Equity Ratio menunjukkan perbandingan antara utang yang dimiliki perusahaan dengan modal sendiri. Semakin besar nilai debt to equity ratio suatu perusahaan berarti semakin tinggi pula persentase utang perusahaan dibandingkan dengan modal sendiri. Hal ini mencerminkan risiko perusahaan yang semakin besar karena adanya risiko yang ditanggung oleh perusahaan. Risiko ini dapat membesar karena utang yang dimiliki terkadang tidak hanya menggunakan mata uang Indonesia, tetapi juga mata uang asing, sehingga dapat memengaruhi perusahaan dalam pembayaran utangnya karena ada risiko fluktuasi nilai tukar. Pengelolaan risiko fluktuasi nilai tukar ini dapat dilakukan melalui kebijakan hedging. Dengan demikian, semakin tinggi leverage maka semakin rendah tindakan melakukan hedging.

\subsubsection{Growth Opportunity Berpengaruh Positif terhadap Hedging}

Hasil pengujian hipotesis keempat menunjukkan bahwa hipotesis keempat ditolak. Hasil pengujian menunjukkan bahwa growth opportunity mempunyai nilai Wald sebesar 2.318 dengan nilai signifikansi sebesar 0.128 yang dimana nilai tersebut lebih besar dari 0,1 
$(\alpha=10 \%)$ dan nilai belta sebesar 0.712. Maka dari itu, berdasarkan hasil hipotesis tersebut menyatakan bahwa growth opportunity tidak berpengaruh positif terhadap keputusan hedging.

Pertumbuhan perusahaan merupakan perubahan total aset baik berupa peningkatan maupun penurunan yang dialami oleh perusahaan selama satu periode (satu tahun) atau dengan kata lain pertumbuhan perusahaan merupakan kemampuan perusahaan untuk meningkatkan ukuran perusahaan. Perusahaan yang memiliki tingkat pertumbuhan tinggi dalam menjalankan perusahaannya akan lebih baik menggunakan ekuitas untuk membiayai segala keperluan dalam meningkatkan pertumbuhan perusahaan agar biaya keagenan tidak terjadi antara manajemen perusahaan dengan pemegang saham. Perusahaan yang mempunyai tingkat pengembalian yang tinggi atas investasi menggunakan utang yang relatif kecil karena tingkat pengembalian yang tinggi memungkinkan perusahaan untuk membiayai sebagian besar pendanaan internal. Dengan kata lain, perusahaan dengan laba ditahan yang besar, akan menggunakan laba ditahannya untuk melakukan ekspansi. Penggunaan laba ditahan dilakukan perusahaan sebagai langkah pencegahan kebangkrutan di masa yang akan datang. Hasil yang tidak signifikan pada variabel growth opportunity dapat disebabkan karena data kontrak yang berfluktuasi selama periode penelitian.

Hasil growth opportunity yang semakin meningkat akan mengindikasikan probabilitas tindakan hedging yang dilakukan perusahaan dengan eksposur transaksi akan menurun. Sebaliknya, perusahaan dengan growth opportunity yang semakin rendah akan mengindikasikan probabilitas tindakan hedging yang dilakukan perusahaan dengan eksposur transaksi akan meningkat. Hasil analisis ini konsisten dengan hasil penelitian Guniari (2014) menyatakan growth opportunity tidak berpengaruh signifikan pada pengambilan keputusan hedging.

Kesempatan pertumbuhan perusahaan yang tinggi menunjukkan nilai pasar yang semakin baik di antara perusahaan lainnya, hal itu membuat perusahaan percaya diri untuk menggunakan dana eksternal untuk penggunaan pertumbuhan perusahaan, selain itu membuat calon investor bersedia menanamkan dananya kepada perusahaan yang memiliki kesempatan pertumbuhan perusahaan yang tinggi, karena dinilai dapat menjadi sarana investasi yang baik. Nilai dari proksi kesempatan pertumbuhan perusahaan yang semakin besar membuat perusahaan lebih banyak menggunakan hutang sebagai sumber dana (Chen, 2006 dalam Sibarani dkk, 2016).

Perusahaan yang memiliki peluang pertumbuhan yang tinggi akan membutuhkan tambahan modal dari pihak luar atau eksternal untuk membiayai kegiatan operasional yang akan dilakukan perusahaan. Baik dana eksternal yang dibutuhkan tersebut dapat diperoleh dari luar maupun dalam negeri, ketika memperoleh dari luar negeri maka akan menghadapi risiko fluktuasi nilai tukar. Ketika mata uang lokal terdepresiasi maka perusahaan akan mengalami kerugian, sehingga untuk meminimalisir risiko tersebut perusahaan akan membutuhkan hedging. Terlihat dalam data penelitian ini bahwa growth opportunity tertinggi yaitu pada Unilever Tbk sebesar 62,90\% dan 82,45\% dan Unilever Tbk melakukan hedging.

Perusahaan yang memiliki growth opportunity yang tinggi menunjukkan bahwa perusahaan tersebut akan memiliki banyak peluang investasi yang menyebabkan perusahaan akan mengalami masalah underinvestment cost atau kurangnya biaya investasi, sehingga perusahaan bisa melakukan aktivitas hedging untuk mengurangi masalah underinvestment cost. Dengan demikian, semakin tinggi nilai growth opportunity maka probabilitas penggunaan hedging akan semakin rendah. 


\subsubsection{Financial Distress Berpengaruh Negatif terhadap Hedging}

Hasil pengujian hipotesis kelima menunjukkan bahwa hipotesis kelima diterima. Hasil pengujian menunjukkan bahwa financial disstres mempunyai nilai Wald sebesar 2.940 dengan nilai signifikansi sebesar 0.086 yang dimana nilai tersebut lebih kecil dari $0,1(\alpha=$ 10\%) dan nilai belta sebesar -1.811. Maka dari itu, berdasarkan hasil hipotesis tersebut menyatakan bahwa financial disstres berpengaruh negatif terhadap keputusan hedging.

Financial distress yang berpengaruh negatif dan signifikan mengindikasikan bahwa semakin tinggi tingkat kesulitan keuangan (altman z-socre rendah) semakin banyak perusahaan yang melakukan aktivitas hedging untuk melindungi perusahaan dari risiko kebangkrutan diakibatkan kewajiban-kewajiban yang berada di posisi tidak aman. Nilai altman z-score yang rendah mendorong perusahaan lebih berhati- hati dalam mengelola risiko termasuk fluktuasi nilai tukar dan suku bunga. Hasil analisis ini konsisten dengan hasil penelitian Sianturi dan Pangestuti (2015), menyatakan financial distress berpengaruh negatif dan signifikan terhadap hedging dan penelitian Putro dan Chabachib (2012), Guniarti (2014), mengemukakan financial distress tidak berpengaruh signifikan terhadap hedging.

Hal ini terbukti berdasarkan data financial distress yang paling tinggi adalah Wilmar Cahaya Indonesia Tbk pada dua tahun berturut-turut, yaitu pada tahun 2016 dan 2017 sebesar $4.80 \%$ dan $4.36 \%$. Berdasarkan data tersebut menunjukkan bahwa financial distress yang diperoleh perusahaan Wilmar Cahaya Indonesia Tbk memiliki nilai financial distress paling tinggi namun Wilmar Cahaya Indonesia Tbk tidak melakukan hedging.

Financial distress merupakan suatu pengukuran yang mengindikasikan kesulitan dalam pengembalian kewajiban perusahaan kepada kreditur, atau dapat disebut sebagai pengukur kebangkrutan perusahaan (Putro dan Chabachib, 2012). Financial distress juga dapat dikatakan sebagai sebuah kondisi dimana perusahaan tidak mampu dalam membayar segala kewajibannya atau tidak terdapatnya dana untuk melunasi hutang jangka panjang maupun jangka pendek perusahaan saat jatuh tempo (Hasymi, 2007). Financial distress biasanya dihadapi oleh perusahaan yang menggunakan utang lebih tinggi di banding dengan modal sendiri (high leverage), financial distress juga dapat disebabkan oleh rendahnya kemampuan perusahaan untuk menghasilkan laba dari proses operasinya (Shaari dkk, 2013 dalam Jiwandhana dan Triaryati, 2016). Financial distress terjadi sebelum perusahaan mengalami kebangkrutan karena financial distress merupakan tahap penurunan kondisi keuangan perusahaan sebelum perusahaan dilikuidasi (Widarjo dan Setiawan, 2009). Kondisi yang mencirikan sedang terjadinya financial distress dalam tubuh sebuah perusahaan harus segera diketahui sejak dini agar dapat dilakukan tindakan-tindakan untuk menghindarkan perusahaan dari kebangkrutan (Haryetti, 2010).

Financial distress disebabkan oleh kesalahan-kesalahan pengambilan keputusan, dan kelemahan-kelemahan yang saling berhubungan yang dapat berdampak secara langsung ataupun tidak kepada manajemen dapat juga disebabkan oleh kurangnya upaya mengawasi kondisi keuangan sehingga penggunaan uang tidak sesuai dengan keperluan. Hasil negatif tersebut menunjukkan ketidaksesuaian tanda dengan hipotesis sehingga nilai Z-Score Altman yang semakin meningkat akan mengindikasikan probabilitas tindakan hedging yang dilakukan perusahaan dengan eksposur transaksi akan menurun. Sebaliknya, perusahaan dengan nilai Z-Score Altman yang semakin rendah akan mengindikasikan probabilitas tindakan hedging yang dilakukan perusahaan dengan eksposur transaksi akan meningkat. Dengan demikian, perusahaan dengan alasan semakin tingginya profitabilitas maka perusahaan akan menghadapi resiko financial distress cost yang lebih kecil dan mengakibatkan perusahaan tidak melakukan hedging (Jiwandhana dan Triaryati, 2016). 


\subsubsection{Firm size Berpengaruh Positif terhadap Hedging}

Hasil pengujian hipotesis keenam menunjukkan bahwa hipotesis keenam diterima. Hasil pengujian menunjukkan bahwa firm size mempunyai nilai Wald sebesar 5.180 dengan nilai signifikansi sebesar 0,023 yang dimana nilai tersebut lebih kecil dari $0,05(\alpha=5 \%)$ dan nilai belta sebesar 1.959. Maka dari itu, berdasarkan hasil hipotesis tersebut menyatakan bahwa firm size berpengaruh positif terhadap keputusan hedging.

Variabel ukuran perusahaan signifikan disebabkan oleh perusahaan melibatkan mata uang yang berbeda. Dalam kegiatannya akan terdapat eksposur transaksi (hutang dan piutang mata uang asing) sehingga tidak terdapat risiko fluktuasi nilai tukar mata uang. Untuk itu perusahaan yang lebih besar akan lebih banyak melakukan aktivitas hedging dalam rangka melindungi perusahaan dari risiko fluktuasi nilai tukar. Hasil analisis ini konsisten dengan hasil penelitian Putro dan Chabachib (2012), Damanik dan Muharam (2015), Sibarani dkk (2016), Istiah (2017), Saragih dan Musdholifah (2017), mengemukakan bahwa firm size berpengaruh positif dan signifikan pada pengambilan keputusan hedging.

Ukuran perusahaan digunakan sebagai salah satu indikator mengenai seberapa besar perusahaan itu telah berkembang. Kadang kala sering dijumpai perbedaan antara perusahaan yang berskala besar dengan perusahaan yang berskala lebih kecil, sebagai contoh dalam hal kemampuan untuk mendapatkan dana atau modal. Perusahaan yang besar umumnya memiliki fleksibilitas dan aksesibilitas yang tinggi dalam masalah pendanaan melalui pasar modal, sehingga perusahaan besar memiliki kemudahan dan kemampuan lebih dalam mendapatkan dana.

Perusahaan yang lebih besar cenderung memiliki sumber permodalan yang lebih terdiversifikasi, sehingga ukuran perusahaan merupakan proksi kebalikan dari kemungkinan kebangkrutan. Biaya menambah hutang dan modal sendiri juga berhubungan dengan ukuran perusahaan. Perusahaan kecil cenderung membayar biaya modal sendiri dan biaya hutang jangka panjang lebih mahal dari pada perusahaan besar, sehingga perusahaan kecil mungkin menyukai hutang jangka pendek daripada meminjam hutang jangka panjang karena biayanya yang lebih rendah.

Salah satu cara yang dapat dilakukan untuk mengelola risiko ini adalah dengan melakukan aktivitas hedging. Semakin besar suatu perusahaan semakin besar risiko yang timbul, maka semakin mungkin perusahaan untuk melakukan hedging. Perusahaan yang lebih besar akan lebih banyak melakukan hedging dibandingkan dengan perusahaan dengan ukuran yang lebih kecil. Hal ini terbukti berdasarkan data leverage yang menunjukkan tingkat nilai yang paling tinggi adalah Kedaung Indag Can Tbk pada dua tahun berturut-turut, yaitu pada tahun 2016 dan 2017 sebesar 18.76\% dan 18.82\%. Berdasarkan data tersebut menunjukkan bahwa firm size yang diperoleh perusahaan Kedaung Indag Can Tbk memiliki nilai firm size paling tinggi dan melakukan hedging. Dengan demikian, semakin tinggi ukuran perusahaan maka akan semakin tinggi keputusan hedging.

\section{SIMPULAN}

Penelitian ini menganalisis faktor-faktor yang berpengaruh terhadap hedging berdasarkan corporate value (nilai perusahaan), liquidity (likuiditas), leverage, growth opportunity (kesempatan tumbuh), financial distress dan firm size (ukuran perusahaan) pada perusahaan manufaktur yang terdaftar di Bursa Efek Indonesia. Pertama, variabel corporate value tidak berpengaruh positif terhadap hedging. Hal ini berarti semakin tinggi corporate value yang diperoleh suatu perusahaan akan membuat hedging semakin rendah. Corporate value tinggi berarti memiliki nilai perusahaan yang tinggi, dan artinya perusahaan akan 
memiliki dana yang cukup tinggi pula. Karena adanya dana yang cukup tinggi tersebut, perusahaan mampu mengatasi risiko yang terjadi karena perubahan mata uang atau kurs dengan dana yang dimiliki tanpa perlu menerapkan hedging. Kedua, variabel liquidity tidak berpengaruh negatif terhadap hedging. Current ratio yang tinggi dari suatu perusahaan akan mengurangi ketidakpastian bagi investor, yang mengindikasikan adanya dana menganggur (idle cash), dengan demikian semakin tinggi likuiditas maka semakin rendah penggunaan instrumen derivatif karena resiko kesulitan keuangan yang muncul cenderung rendah dan perusahaan juga memiliki cadangan dana untuk menghadapi resiko. Ketiga, variabel leverage berpengaruh negatif terhadap hedging. Leverage yang merupakan rasio yang digunakan untuk mengukur sejauh mana perusahaan dibiayai dengan hutang. Sebuah perusahaan yang mempunyai rasio leverage tinggi, maka semakin tinggi pula resiko yang dihadapi perusahaan dikarenakan suku bunga yang lebih tinggi sehingga manajemen akan meminimalisir resiko tersebut dengan melakukan aktivitas hedging.

Keempat, variabel growth opportunity tidak berpengaruh positif terhadap hedging. Perusahaan yang memiliki growth opportunity yang tinggi menunjukkan bahwa perusahaan tersebut akan memiliki banyak peluang investasi yang menyebabkan perusahaan akan mengalami masalah underinvestment cost atau kurangnya biaya investasi, sehingga perusahaan bisa melakukan aktivitas hedging untuk mengurangi masalah underinvestment cost. Dengan demikian, semakin tinggi nilai growth opportunity maka probabilitas penggunaan hedging akan semakin rendah. Kelima, variabel financial disstres tidak berpengaruh negatif terhadap hedging. Hal ini berarti semakin tinggi financial disstres yang diperoleh suatu perusahaan akan membuat hedging semakin rendah. Semakin tinggi tingkat kesulitan keuangan (altman z-socre rendah) semakin banyak perusahaan yang melakukan aktivitas hedging untuk melindungi perusahaan dari risiko kebangkrutan diakibatkan kewajiban-kewajiban yang berada di posisi tidak aman. Keenam, variabel firm size berpengaruh positif terhadap hedging. Hal ini berarti semakin tinggi firm size yang diperoleh suatu perusahaan akan membuat hedging semakin tinggi. Perusahaan yang lebih besar akan lebih banyak melakukan hedging dibandingkan dengan perusahaan dengan ukuran yang lebih kecil.

Berdasarkan hasil simpulan yang telah dikemukakan di atas, maka penulis memberikan beberapa saran yang mungkin dapat bermanfaat. Bagi peneliti selanjutnya disarankan untuk menambah variabel internal perusahaan lainnya atau dapat menggunakan variabel yang sama dalam penelitian ini tetapi dengan menggunakan alat ukur yang berbeda, dan juga agar dapat menambah objek penelitian dengan menggunakan seluruh perusahaan non keuangan yang terdaftar di Bursa Efek Indonesia atau dengan menggunakan industri yang berbeda serta memperpanjang periode penelitian. Bagi perusahaan manufaktur yang akan melakukan pengambilan keputusan hedging diharapkan untuk memperhatikan informasi internal perusahaan yaitu corporate value, liquidity, leverage, growth opportunity, financial disstres, firm size, dividend policy, institutional ownership. Hal ini perlu dilakukan untuk mencegah perusahaan mendapat risiko eksposur valuta asing yang seharusnya dapat dialihkan oleh penggunaan instrumen derivatif sebagai sarana hedging, dan mencegah perusahaan untuk mengeluarkan biaya derivatif dengan tidak memberikan manfaat yang diharapkan. Bagi investor yang akan melakukan investasi ke berbagai perusahaan manufaktur dengan yang terdaftar di Bursa Efek Indonesia dapat memperhitungkan terlebih dahulu variabel corporate value, liquidity, leverage, growth opportunity, financial disstres, firm size yang dimiliki perusahaan tersebut. Bila nilai yang ditunjukkan oleh perhitungan variabel tersebut menunjukkan angka yang relatif tinggi dibandingkan dengan perusahaan lain, tetapi dengan perusahaan tersebut belum melakukan aktivitas hedging maka perusahaan tersebut berisiko terjadinya kesulitan keuangan karena risiko yang diterima perusahaan lebih besar. 


\section{DAFTAR PUSTAKA}

Andardini, Winda Rosa. 2016. Keputusan Hedging dan Faktor-faktor yang Mempengaruhi (Studi Empiris pada Perusahaan Manufaktur yang Terdaftar di BEI 2012-2014). Jurnal Eprint Sekolah Tinggi Ilmu Ekonomi Perbanas Hal 1-16. [Online] (Diakses http://eprints.perbanas.ac.id/1736/1/ARTIKEL\%20ILMIAH.pdf, tanggal 01 Juli 2018).

Aslikan, Indra \& Rokhmi, Siti. 2017. Faktor-Faktor yang Mempengaruhi Keputusan Hedging pada Perusahaan Manufaktur. Jurnal Ilmu dan Riset Manajemen Vol. 6 No. 5 Hal. $1-21$.

Damanik, Hepdityo Rizki Adam \& Muharam, Harjum. 2015. Keputusan Lindung Nilai dan Faktor-Faktor yang Mempengaruhi (Studi Empiris pada Bank Konvensional yang Terdaftar di BEI Periode 2009-2013). Diponegoro Journal of Management Vol. 4 No. 2 Hal. 1-13.

Dewi, Ni Komang Reni Utami \& Purnawati, Ni Ketut. 2016. Pengaruh Market to Book Value dan Likuiditas terhadap Keputusan Hedging pada Perusahaan Manufaktur di BEI. EJurnal Manajemen Unud Vol. 5 No. 1 Hal. 355-384.

Goklas, Fernando \& Wahyudi, Sugeng. 2016. Kebijakan Hedging dan Faktor-faktor yang Mempengaruhinya (Studi Empiris pada Perusahaan Non Finansial yang Terdaftar di BEI Periode 2012-2014). Diponegoro Journal of Management Vol. 5 No. 4 Hal. 114.

Guniarti, Fay. 2014. Faktor-Faktor yang Mempengaruhi Aktivitas Hedging dengan Instrumen Derivatif Valuta Asing. Jurnal Dinamika Manajemen Vol. 5 No. 1 Hal. 64-79.

Haryetti. 2010. Analisis Financial Distress untuk Memprediksi Resiko Kebangkrutan Perusahaan (Studi Kasus pada Industri Perbankkan di BEI). Jurnal Ekonomi Vol. 18 No. 2 Hal. 1-14.

Hasymi, Muhammad. 2007. Analisis Penyebab Kesulitan Keuangan (Financial Distress) Studi Kasus: Pada Perusahaan Bidang Konstruksi PT. X. Universitas Diponegoro, Semarang. [Online] (Diakses http://eprints.undip.ac.id/10316/1/2007MAK6417.pdf, tanggal 15 Juli 2018).

Istiah, Rizki Nur. 2017. Analisis Faktor yang Mempengaruhi Penggunaan Instrumen Derivatif sebagai Pengambilan Keputusan Hedging (Studi Empiris Perusahaan Automotive and Allied Products yang Terdaftar di Bursa Efek Indonesia Periode 2011-2016). Jurnal Umrah Universitas Maritim Raja Ali Haji Hal 1-20. [Online] (Diakses http://jurnal.umrah.ac.id/?p=8041, tanggal 20 Juli 2018).

Jiwandhana, R.M. Satwika Putra \& Triaryati, Nyoman. 2016. Pengaruh Leverage, dan Profitabilitas terhadap Keputusan Hedging Perusahaan Manufaktur Indonesia. EJurnal Manajemen Unud Vol. 5 No.1 Hal. 31-58.

Khediri, Karim Ben. 2010. Do Investors Really Value Derivatives Use? Empirical Evidence from France. The Journal of Risk Finance Vol.11 No. 1 Hal. 62-74.

Kuncoro, Mudrajad. 2001. Metode Kuantitatif: Teori dan Aplikasi untuk Bisnis dan Ekonomi. AMP YKPN: Yogyakarta.

Madura, Jeff. 2006. Keuangan Perusahaan Internasional. Buku 1 Edisi Delapan. Terjemahan Yanivi S. Salemba Empat: Jakarta.

Mediana, Ima \& Muharam, Harjum. 2016. Analisis Faktor-Faktor yang Mempengaruhi Pengambilan Keputusan Lindung Nilai (Hedging) Menggunakan Instrumen Derivatif (Studi Kasus pada Perusahaan Manufaktur dan Perusahaan Energi Dan Sumber Daya Mineral yang Terdaftar di BEI Periode 2010-2014). Diponegoro Journal of Management Vol. 5 No. 2 Hal. 1-14.

Munawir. S. 2007. Analisa Laporan Keuangan. Liberty; Yogyakarta. 
Munthe, Abraham Esra. 2016. Analisis Faktor yang Mempengaruhi Penggunaan Instrumen Derivatif sebagai Pengambil Keputusan Hedging pada Perusahaan Manufaktur yang Terdaftar di Bursa Efek Indonesia. Universitas Sumatera Utara, Medan. [Online](http://repositori.usu.ac.id/bitstream/handle/123456789/991/120502228.pdf? sequence=1\&isAllowed=y, tanggal 7 Juli 2018).

Paranita, Ekayana Sangkasari. 2011. Kebijakan Hedging dengan Derivatif Valuta Asing pada Perusahaan Publik di Indonesia. Paper dipresentasikan pada Seminar Nasional Ilmu Ekonomi Terapan.Fakultas Ekonomi UNIMUS.

Putro, Septama Hardanto \& Chabachib, Mochammad. 2012. Analisis Faktor yang Mempengaruhi Penggunaan Instrumen Derivatif sebagai Pengambilan Keputusan Hedging (Studi Kasus pada Perusahaan Automotive and Allied Products yang Terdaftar Di BEI Periode 2006-2010). Diponegoro Business Review Vol. 1 No. 1 Hal. $1-11$.

Saragih \& Musdholifah. 2017. Pengaruh Growth Opportunity, Firm Size, Liquidity pada Perusahaan Perbankan Indonesia. Jurnal Ilmu Manajemen Vol. 5 No. 2 Hal. 1-10.

Sartono, R. Agus. 2014. Manajemen Keuangan: Teori dan Aplikasi. Edisi 4. BPFE: Yogyakarta.

Sherlita, Erly. 2007. Peranan Aktivitas Lindung Nilai dalam Menurunkan Risiko Perdagangan Internasional. Jurnal Bisnis, Manajemen dan Ekonomi Vol. 8 No. 3 Hal. 1227-1238.

Sianturi \& Pangestuti. 2015. Pengaruh Liquidity, Firm Size, Growth Opportunity, Financial Disstres, Leverage dan Managerial Ownership terhadap Aktivitas Hedging dengan Instrumen Derivatif. Diponegoro Journal of Management Vol. 4 No. 4 Hal. 1-13.

Sibarani, Josua Peter Adi Nugroho; Irfan, Andi \& Rahmi, Febri. 2016. Faktor-Faktor dalam Pengambilan Keputusan Lindung Nilai pada Instrumen Derivatif Valuta Asing. . Paper dipresentasikan pada Simposium Nasional Akuntansi, UNILA, Lampung tanggal 24 Agustus 2016.

Subramanyam, K.R. \& Wild, John J. 2010. Analisa Laporan Keuangan. Edisi Sepuluh. Terjemahan Dewi Yanti. Salemba Empat: Jakarta.

Sunaryo, T. 2009. Manajemen Risiko Finansial. Salemba Empat :Jakarta.

Utomo, Lisa Linawati. 2000. Instrumen derivatif: Pengenalan dalam Strategi Manajemen Risiko Keuangan. Jurnal Akuntansi dan Keuangan Vol. 2 No. 1 Hal. 53-68.

Verawaty, 2013. The Accessibility Determinants of Internet Financial Reporting in Banking Website Listed in Indonesia Stock Exchange. Paper dipresentasikan pada Seminar Internasional 8th Asian Business Research Conference, Bangkok, Thailand, 1-2 April 2013.

Verawaty; Merina, C.I., \& Kurniawati, I. 2016. Analisis Pengembangan Corporate Value Berdasarkan Keputusan Investasi dan Pendanaan, Struktur Kepemilikan serta Kebijakan Dividen pada Perusahaan Manufaktur di Bursa Efek Indonesia. Jurnal Berkala Akuntansi dan Keuangan Indonesia (BAKI) Vol. 1 No. 1 Hal 15-34.

Widarjo Wahyu \& Setiawan, Doddy. 2009. Pengaruh Rasio Keuangan terhadap Financial Distress Perusahaan Otomotif. Jurnal Bisnis dan Akuntansi, Vol. 11 No. 2 Hal 107119.

Widyagoca, I Gusti Putu Agung \& Lestari, Putu Vivi. 2016. Pengaruh Growth Opportunity, Leverage, Liquidity terhadap Pengambilan Keputusan Hedging pada PT. Indosat Tbk.. E-Jurnal Manajemen Unud Vol. 5 No. 2 Hal. 1282-1308. 